\title{
Surfactant apoprotein A modulates interleukin-8 and monocyte chemotactic peptide-1 production
}

\author{
F. Meloni*, A. Alberti", A. Bulgheroni*, A. Lupi*, E. Paschetto*, A. Marone Bianco*, G. Rodi ${ }^{\mp}$, \\ A. Fietta*, M. Luisetti*, A. Baritussio\#
}

Surfactant apoprotein A modulates interleukin-8 and monocyte chemotactic peptide-1 production. F. Meloni, A. Alberti, A. Bulgheroni, A. Lupi, E. Paschetto, A. Marone Bianco, G. Rodi, A. Fietta, M. Luisetti, A. Baritussio. (C) ERS Journals Ltd 2002.

ABSTRACT: Previous studies have shown that surfactant apoprotein A (SP-A) and natural or synthetic surfactant can modulate the release of pro-inflammatory cytokines from alveolar mononuclear phagocytes.

The aim of this study was to assess whether SP-A or Surfactant (Surf) from patients with pulmonary alveolar proteinosis (PAP) can affect the release of two chemokines (interleukin (IL)-8 and monocyte chemtactic peptide (MCP)-1) from human monocytes and rat lung type-II cells. In addition IL-8 and MCP-1 levels were assessed in the brochoalveolar lavage fluid (BALF) of seven patients with PAP and compared with those in a group of control subjects $(n=5)$.

SP-A, tested over a wide range of concentrations, significantly increased IL-8 and MCP-1 release from monocytes. SP-A retained its activity after collagenase digestion, but was not active after heat treatment. The release of IL-8 by monocytes was also stimulated by Surf. Finally, median BALF IL-8 and MCP-1 levels in PAP patients were significantly higher than in controls $\left(9.50\right.$ and $9.51 \mathrm{pg} \cdot \mathrm{mL}^{-1}$ in controls versus 151.95 and $563.70 \mathrm{pg} \cdot \mathrm{mL}^{-1}$ in PAP, respectively) and significantly correlated with SP-A concentrations in BALF.

Overall the results of this study support the view that the high content of alveolar surfactant apoprotein A may contribute to the upregulation of chemokine release in pulmonary alveolar proteinosis, thus contributing to airway inflammation. Eur Respir J 2002; 19: 1128-1135.

\begin{abstract}
*Dept of Haematological, Pneumological and Cardiovascular Sciences, Respiratory Diseases Section and Clinic of Respiratory Diseases, University of Pavia and Istituto di Ricovero e Cura a Carattere Scientifico Policlinico San Matteo, Pavia, ${ }^{\text {\#Insti- }}$ tute of Internal Medicine, University of Padova, Padova and "First Intensive Care Unit, and Istituto di Ricovero e Cura a Carattere Scientifico Policlinico San Matteo, Pavia, Italy.
\end{abstract}

Correspondence: F. Meloni, Dipartimento di Scienze Ematologiche, Pneumologiche e Cardiovascolari mediche e chirurgiche, Sezione di Pneumologia, Universita di Pavia, I.R.C.C.S. Policlinico San Matteo, Padiglione Forlanini, Via Taramelli 5, 27100 Pavia, Italy. Fax: 390382422267

E-mail: federica-meloni@libero.it

Keywords: Chemokines, interleukin-8, monocyte chemotactic peptide-1, pulmonary alveolar proteinosis, surfactant, surfactant apoprotein-A

Received: February 22001

Accepted after revision December 13 2001
Pulmonary surfactant is a complex mixture of phospholipids and proteins whose main function is to lower surface tension at the air-liquid interface in the lungs and thus protect the alveoli from collapse at the end of expiration. The major surfactantassociated protein is surfactant apoprotein A (SPA), a member of the C-type lectin family which also includes SP-D. These proteins share a collagen-like domain and a domain which binds carbohydrates in a calcium-dependent manner (CRD) [1, 2]. Several functions have been attributed to SP-A, including the modulation of defence against pathogens [3, 4]. In fact, SP-A enhances attachment [5-7], chemotaxis, phagocytosis, and oxygen-dependent killing [8-14] of specific respiratory pathogens in monocytes and alveolar macrophages. In addition, SP-A stimulates the production of many pro-inflammatory cytokines by human type-II cells or monocytes $[15,16]$ and the release of tumour necrosis factor (TNF)- $\alpha$, interleukin (IL) $-1 \beta$, IL- 6 and IL- 8 by the monocytic THP- 1 cell line [17]. The effect of SP-A on TNF- $\alpha$ release was inhibited by surfactant lipids, suggesting that in physiological conditions the effect of SP-A might be counteracted by other surfactant components. Among pro-inflammatory cytokines, great interest has been given to chemokines, a family of proteins whose main biological function is the selective control of the migration of certain leukocyte subpopulations to sites of inflammation. Two chemokines, IL-8 and monocyte chemotactic peptide (MCP)-1 have been shown to play a role in several pathological lung conditions, including infections and fibrotic lung diseases [18, 19]. Major cellular sources of IL-8 and MCP-1 in the lung are macrophages and type-II cells [20].

In this paper the effect of SP-A or unfractionated surfactant on IL-8 and MCP-1 release from human monocytes and rat lung type-II epithelial cells was studied. Having found that SP-A stimulates IL- 8 and MCP-1 release, their concentrations in the bronchoalveolar lavage fluid (BALF) of patients affected by pulmonary alveolar proteinosis (PAP), a condition characterized by an excess of surfactant components (especially SP-A) in the airways, was measured. 


\section{Methods}

\section{Bronchoalveolar lavage}

Bronchoalveolar lavage (BAL) was collected from seven patients with idiopathic PAP and from five volunteers without lung disease. The seven PAP patients belonged to a cohort of 12 subjects enrolled in the whole lung-lavage programme of the Policlinico San Matteo, Pavia [21]. The diagnosis of idiopathic PAP was made from lung biopsy, SP-A measurement in bronchoalveolar lavage fluid (BALF), highresolution computed tomography scans and exclusion of underlying conditions. The seven PAP patients (five males and two females) were aged 27-56 yrs (mean age 43). The five unaffected volunteers (three males and two females) aged 22-51 yrs (mean 39 yrs), had BAL because of haemoptysis or cough of unknown origin. All participants had given their informed consent to the study, which was approved by the ethical board of the Istituto di Ricovero e Cura a Carattere Scientifico, San Matteo, Pavia. Fibreoptic bronchoscopy was carried out as described previously [22]. BAL cells were counted and used for cytospin preparations. BALF was used for nephelometric albumin determination (Beckman, Brea, CA, USA), concentrated by ultrafiltration (Centriplus-3; Amicon Inc., Beverly, MA, USA) and stored at $-80^{\circ} \mathrm{C}$.

\section{Isolation of human surfactant and human surfactant apoprotein $A$}

Human surfactant (Surf) was purified from BALF obtained from patients with PAP [23]. The BALF was centrifuged at $85,000 \times g$ for $45 \mathrm{~min}$, the pellet was suspended in $5 \mathrm{mM} \mathrm{N}$-2-hydroxyethylpiperazine-N-2ethanesulfonic (HEPES), $1 \mathrm{mM} \mathrm{CaCl} 2,2 \mathrm{M}$ sucrose, $\mathrm{pH} 7.4$ and centrifuged at $100,000 \times g$ for $16 \mathrm{~h}$ in a SW 28 rotor. Floating materials were suspended in $5 \mathrm{mM}$ HEPES, $145 \mathrm{mM} \mathrm{NaCl}, 1 \mathrm{mM} \mathrm{CaCl}$, pH 7.4, sedimented at $85,000 \times g$ for $30 \mathrm{~min}$ and the pellet was suspended in distilled water and stored at $-80^{\circ} \mathrm{C}$.

SP-A was isolated by butanol extraction of BALF from patients with PAP as described [24]. The purity of isolated SP-A was confirmed by two-dimensional gel electrophoresis and silver staining or by autoradiography after labelling with 125 iodine [25]. SP-A was dissolved in $5 \mathrm{mM}$ tris(hydroxymethyl)aminomethane $\mathrm{pH} 7.4$ at $1 \mathrm{mg} \cdot \mathrm{mL}^{-1}$ and stored at $-80^{\circ} \mathrm{C}$.

In some experiments, heat treated SP-A (boiled for $15 \mathrm{~min}$ ) or reduced and alkylated SP-A (ALSP-A) were used. For ALSP-A, SP-A was incubated with $0.1 \mathrm{M}$ dithiothreitol for $1 \mathrm{~h}$ at $37^{\circ} \mathrm{C}$, then $0.1 \mathrm{M}$ of iodoacetamide was added and the incubation continued for $1 \mathrm{~h}$ at room temperature in the dark, before extensive dialysis against $5 \mathrm{mM}$ Tris, $\mathrm{pH}$ 7.4.

In other experiments, collagenase-resistant fragments (CRF) of SP-A were prepared as described previously [26]. Briefly, $0.5 \mathrm{mg} \mathrm{SP}-\mathrm{A}$ in $50 \mathrm{mM}$ Tris,

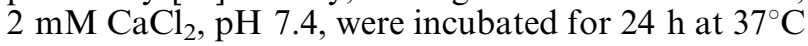
in the presence of 250 units of collagenase type-III from Clostridium histolyticum (Calbiochem, San Diego, CA, USA). Then, the buffer composition of digested
SP-A was changed to binding buffer (BB: $5 \mathrm{mM}$ Tris, $100 \mathrm{mM} \mathrm{NaCl}, 25 \mathrm{mM} \mathrm{CaCl}$, pH 7.4) by buffer exchange on a 10 DG column (Bio Rad, Hercules, CA, USA). Digested SP-A was then applied to a $2 \mathrm{~mL}$ mannose-sepharose $4 \mathrm{~B}$ column pre-equilibrated with $\mathrm{BB}$, and unbound materials were washed away with 10 volumes of BB. Digested SP-A was eluted with 5 volumes of $5 \mathrm{mM}$ Tris, $100 \mathrm{mM} \mathrm{NaCl}, 2 \mathrm{mM}$ ethylenediamine tetraacetic acid, $\mathrm{pH} 7.4$.

SP-A concentration was measured by antigen inhibition enzyme-linked immunosorbent assay (ELISA) [27] and was always expressed as $\mu \mathrm{g} \cdot \mathrm{mL}^{-1}$. The calculated lipid/SP-A ratio of purified human surfactant was 1:179.

All preparations of Surf or SP-A were tested for endotoxin contamination by the Limulus amebocyte lysate assay (Limusate, Haemachem Inc, St. Louis, MO, USA). Some experiments were also carried out with endotoxin free SP-A (ef-SP-A) which was purified with polymyxin B-agarose and octyl-glucopyranoside (Sigma Cheminal Co, St Louis, MO, USA) as described previously [28].

All concentrated Surf and SP-A preparations were also assessed for the content of IL- 8 , MCP-1, TNF- $\alpha$ and interferon (IFN)- $\gamma$. The latter two factors are known to upregulate chemokine release by mononuclear cells. Cytokine levels were always below the detection limits of the commercial assays. In some experiments SP-A preparations were pretreated with $2 \mathrm{M} \alpha$-methy- $D$-mannopyranoside (Aldrich Chemie, Steinheim, Germany) for $30 \mathrm{~min}$ at room temperature, dialysed in water and used for monocyte stimulation.

\section{Monocyte culture}

Human peripheral mononuclear cells (MNC) were isolated from buffy coats of blood donors by density gradient centrifugation in Ficoll-Hypaque (Pharmacia, Uppsala, Sweden): $450 \times g$ for $20 \mathrm{~min}$ at $20^{\circ} \mathrm{C}$. MNC were washed twice, suspended in Roswell Park Memorial Institute (RPMI) medium (Sigma Chemical $\mathrm{Co}$ ), counted and adhered for $2 \mathrm{~h}$ at $37^{\circ} \mathrm{C}$ in an atmosphere of $5 \%$ carbon dioxide $\left(\mathrm{CO}_{2}\right)$. Nonadherent cells were then cultured in RPMI medium (with the addition of antibiotics (Sigma Chemical Co) and $2 \mathrm{mM}$ glutamine) \pm the different stimuli. Collected cell-free supernatants were stored at $-80^{\circ} \mathrm{C}$.

\section{Pulmonary rat type-II alveolar epithelial cells isolation and culture}

Freshly isolated rat type-II alveolar epithelial cells were obtained as described previously [29]. Type-II cells were seeded at $3 \times 10^{6}$ cells $\cdot \mathrm{mL}^{-1}$ in 24 -well dishes and cultured for $72 \mathrm{~h}$ with or without ef-SP-A.

\section{Myeloperoxidase release assay}

A biological assay of myeloperoxidase release from human neutrophil [30] was used to determine the 
activity of different stimuli. These included recombinant rat cytokine induced neutrophil chemoattractant-1 (CINC-1) (R\&D Systems, Minneapolis, MN, USA), formyl-methionyl-leucyl-peptide (FMLP), IL-8 and the supernatants from cultured rat type-II cells. The assay was performed on cytochalasin-B pretreated human neutrophils and the release of myeloperoxidase obtained after stimulation with type-II cell culture supernatants was compared with that obtained with CINC-1 and IL-8. In addition, CINC-1 or type-II supernatants were also preincubated for $60 \mathrm{~min}$ at room temperature with $20 \mu \mathrm{g} \cdot \mathrm{mL}^{-1}$ of blocking anti rat-CINC-1 polyclonal antibodies (R\&D Systems).

Interleukin-8, monocyte chemotactic peptide-1, tumour necrosis factor $-\alpha$ and interferon- $\gamma$ determinations

Concentrations of human IL-8, human MCP-1 and human TNF- $\alpha$ were quantified by an ELISA kit (R\&D Systems), while human IFN- $\gamma$ and rat MCP-1 were assessed by a kit purchased from Endogen (Wolburn, MA, USA). Assays were done in duplicate and results are expressed as means $\pm \mathrm{SD}$.

\section{Statistical analysis}

Results are expressed as means \pm SD of 5-9 separate experiments. Given the non-normal distribution of variables, nonparametric tests were applied (Wilcoxon's signed-rank test, Mann-Whitney U-test, or Spearman's rank correlation coefficient). The level of significance accepted was $5 \%$.

\section{Results}

Effect of purified human surfactant apoprotein $A$ on interleukin-8 and monocyte chemotactic peptide-1 release from human monocytes and rat type-II lung cells

The effect of SP-A on IL-8 and MCP-1 release from human monocytes after a 24 -h stimulation is shown in figure 1. SP-A upregulated IL-8 release from monocytes (fig. 1a). The lowest concentration inducing a significant effect was $1 \mu \mathrm{g} \cdot \mathrm{mL}^{-1}$ and the highest was $10 \mu \mathrm{g} \cdot \mathrm{mL}^{-1}$. The effect of SP-A stimulatory activity on IL-8 was due to de novo synthesis of the chemokine, since the addition of $2 \mathrm{mM}$ cycloheximide to SP-A in the cultures abolished IL- 8 release by monocytes (data not shown). MCP-1 release from monocytes was also affected by SP-A but significant activity was evident only at $10 \mu \mathrm{g} \cdot \mathrm{mL}^{-1}$ (fig. $1 \mathrm{~b}$ ). The stimulatory activity of SP-A was not due to lipopolysaccharide (LPS) contamination of the preparation. For all SP-A and surfactant preparations, LPS levels were $<0.001 \mathrm{ng} \cdot \mathrm{mg}^{-1}$ of SP-A. In addition, no decrease of SP-A activity was detected in the presence of $1 \mu \mathrm{g} \cdot \mathrm{mL}^{-1}$ polymyxin B. Ef-SP-A retained a stimulatory activity on IL-8 comparable to that of SP-A purified only by butanol extraction (table 1).

Since type-II cells are another important cellular
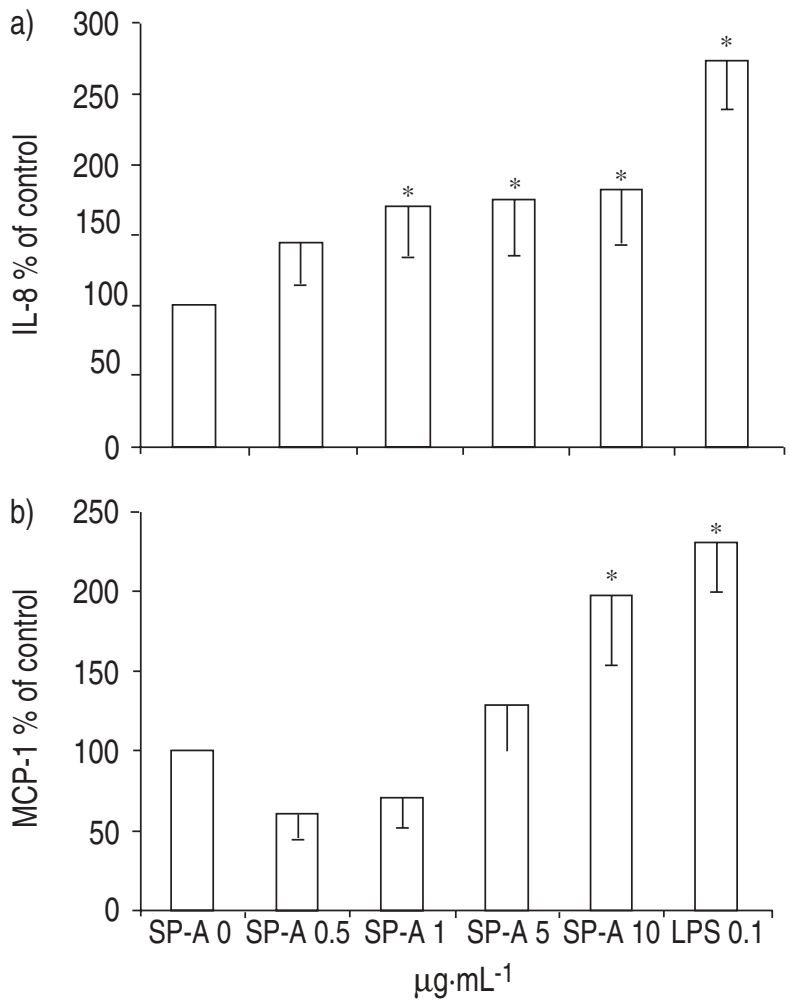

Fig. 1. - a) Interleukin (IL)-8 and b) monocyte chemotactic peptide (MCP)-1 release from human peripheral monocytes cultured $(24 \mathrm{~h})$ with different concentrations of purified human surfactant apoprotein (SP)-A. Lipopolysaccharide (LPS) was used as a positive stimulus. Data are presented as mean \pm SD. *: $\mathrm{p}<0.05$ with respect to control cells.

source of chemokines in the lungs, the effect of ef-SPA on freshly isolated rat lung type-II cells was tested, determining biologically, by means of the myeloperoxidase release assay, the release of rat CINC-1 (the rat counterpart of human IL-8) and assessing the release of rat MCP-1 by ELISA. Rat type-II cells produced a neutrophil stimulatory activity even in basal conditions but this production was significantly

Table 1. - Interleukin (IL)-8 release from human peripheral monocytes stimulated either with lipopolysaccharide (LPS) or purified human surfactant protein-A (SP-A) in the presence or absence of polymyxin $B\left(1 \mu \mathrm{g} \cdot \mathrm{mL}^{-1}\right)$ or with endotoxin-free-surfactant associated protein-A (ef-SP-A)

\begin{tabular}{ll}
\hline Stimulus & $\mathrm{IL}-8 \mathrm{ng} \cdot \mathrm{mL}^{-1}$ \\
\hline None & $1.95 \pm 0.07$ \\
Polymyxin B & $2.05 \pm 0.19$ \\
LPS 0.1 $\mu \mathrm{g} \cdot \mathrm{mL}^{-1}$ & $4.03 \pm 1.16$ \\
LPS 0.1 $\mu \mathrm{g} \cdot \mathrm{mL}^{-1}+$ polymyxin B & $2.15 \pm 0.62$ \\
SP-A $1 \mu \mathrm{g} \cdot \mathrm{mL}^{-1}$ & $2.71 \pm 1.21^{*}$ \\
SP-A $1 \mu \mathrm{g} \cdot \mathrm{mL}^{-1}+$ polymyxin B & $2.86 \pm 0.12^{*}$ \\
SP-A 5 $\mu \mathrm{g} \cdot \mathrm{mL}^{-1}$ & $3.58 \pm 0.68^{*}$ \\
SP-A 5 $\mu \mathrm{g} \cdot \mathrm{mL}^{-1}+$ polymyxin B & $3.59 \pm 0.22^{*}$ \\
ef-SP-A $1 \mu \mathrm{g} \cdot \mathrm{mL}^{-1}$ & $3.55 \pm 0.66^{*}$ \\
ef-SP-A $5 \mu \mathrm{g} \cdot \mathrm{mL}^{-1}$ & $4.11 \pm 0.31^{*}$ \\
\hline
\end{tabular}

Data are presented as mean \pm SD. $*:$ p $<0.05$ with respect to control cells. 


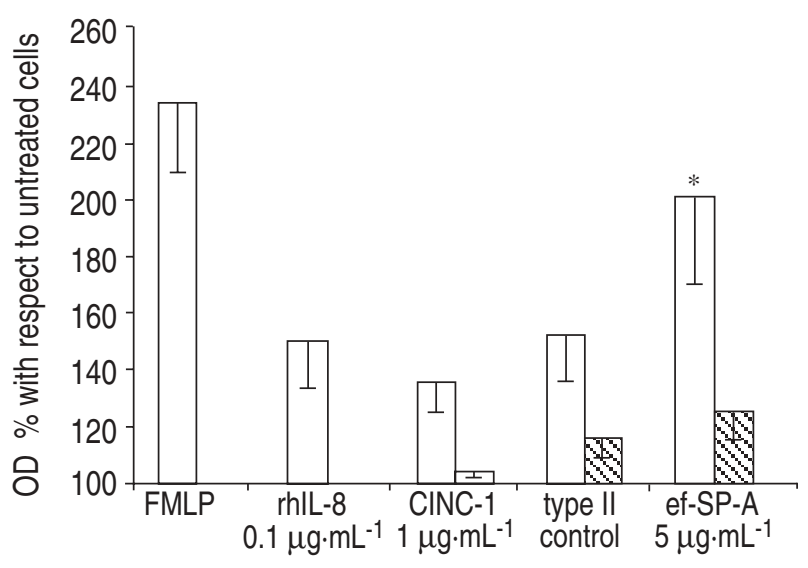

Fig. 2.-Myeloperoxidase release assay of cytochalasin-B treated human neutrophils with formyl-methionyl-leucyl-peptide (FMLP), recombinant human interleukin (IL)-8 and recombinant rat cytokine induced neutrophil chemoattractant (CINC)-1 as positive stimuli. Rat type-II cell supernantants cultured for $72 \mathrm{~h}$ in the absence (type-II control) or presence of endotoxin free surfactant apoprotein A (ef-SP-A). CINC-1 and rat type-II cell supernatants pre-incubated with anti-CINC-1 neutralizing antibody $(\mathbb{\mathbb { N }})$. OD: optical density. Data are presented as mean \pm SD of three separate experiments. ${ }^{*}: \mathrm{p}<0.05$ with respect to type-II control cells.

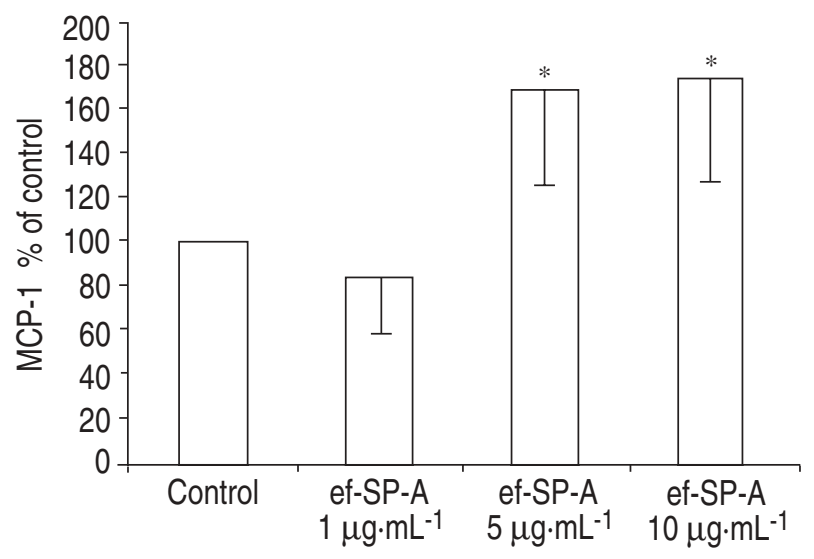

Fig. 3. - Release of rat monocyte chemotactic peptide (MCP)-1 by freshly isolated rat type-II cells in the presence or absence of different concentrations of endotoxin-free surfactant apoprotein A (ef-SP-A). Data are presented as mean \pm SD. ${ }^{*}: \mathrm{p}<0.05$ with respect to control cells.

(32\%) increased upon SP-A treatment (fig. 2). Anti CINC-1 neutralizing antibody did not completely abolish this effect. MCP-1 release by rat type-II cells was also affected by SP-A (fig. 3): ef-SP-A was active at 5 and $10 \mu \mathrm{g} \cdot \mathrm{mL}^{-1}$ producing an increase of $68 \%$ and $73 \%$, respectively over basal levels.

Effect of modified surfactant apoprotein $A$ on the release of interleukin-8 from human monocytes

In an attempt to clarify the mechanism by which SP-A induces IL-8 release, its activity under several experimental conditions was assessed: boiled SP-A, SP-A pretreated with $\alpha$-MMP, CRF and ALSP-A (fig. 4). Heat treatment of SP-A completely abolished

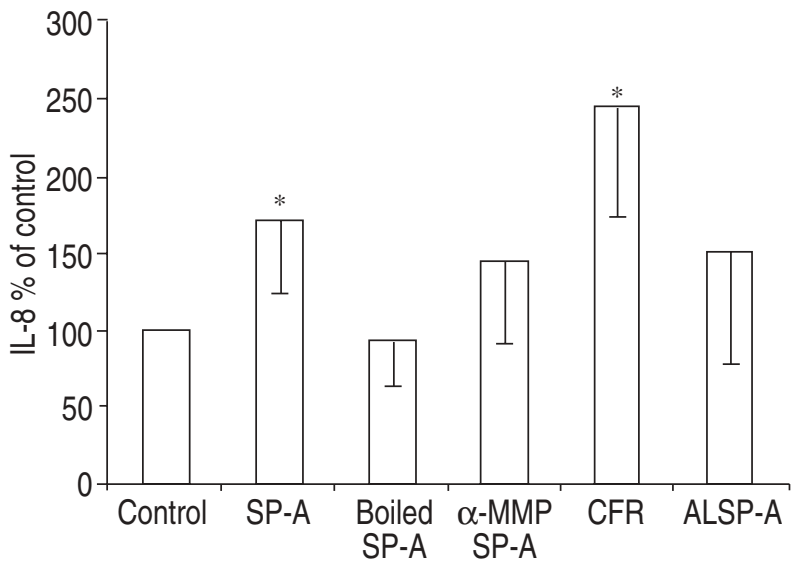

Fig. 4. - Interleukin (IL)-8 release from human peripheral monocytes after simulation with purified human surfactant apoprotein A (SPA), boiled SP-A, SP-A pretreated with $\alpha$-methyl- $D$-mannopyranoside $(\alpha$-MMP SP-A), collagenase-resistant fragment (CRF) of SP-A and alkylated SP-A (ALSP-A) (all $\left.1 \mu \mathrm{g} \cdot \mathrm{mL}^{-1}\right)$. Data are presented a mean $\pm S D$ of three separate experiments. *: $\mathrm{p}<0.05$ with respect to control cells.

its activity on IL-8 release, while pretreatment with $\alpha$-MMP or ALSP-A of SP-A produced a slight but not significant decrease of its effect. The effect of CRF was higher than that of SP-A alone when used at the same concentration. However, since the molecular weight of the CRF may be as much as one-third than that of native SP-A, a given weight of CRF contains more molecules than native SP-A.

\section{Effect of unfractionated human surfactant on interleukin-8 and monocyte chemotactic peptide-1 release from human monocytes}

In order to assess whether SP-A stimulatory activity is influenced by the presence of surfactant lipids the activity of Surf on monocytes was also tested. As shown in figure 5, unfractionated surfactant obtained from PAP patients (Surf), which contains surfactant lipids and surfactant associated proteins, displayed a stimulatory effect on IL-8 release analogous to that produced by equivalent concentrations of purified SP-A alone (fig. 1a). The effect of Surf was compared with the effect of Curosurf (Chiesi Pharmaceuticals, Parma, Italy) and Exosurf (GlaxoSmithKline, Uxbridge, UK). Exosurf did not affect IL-8 release by monocytes while Curosurf slightly but not significantly stimulated IL-8 release. Moreover, Exosurf did not influence IL- 8 release by SP-A treated monocytes. In respect to $\mathrm{MCP}-1$ release, the activity of Surf was evident only at very high doses corresponding to $4.47 \mathrm{pg} \cdot \mathrm{mL}^{-1}$ phospholipids. Exosurf and Curosurf did not show any significant activity.

Levels of interleukin-8 and monocyte chemotactic peptide-1 in bronchoalveolar lavage fluid from patients with pulmonary alveolar proteinosis

After establishing the effect of SP-A and Surf on IL-8 and MCP-1 release from monocytes and type-II 


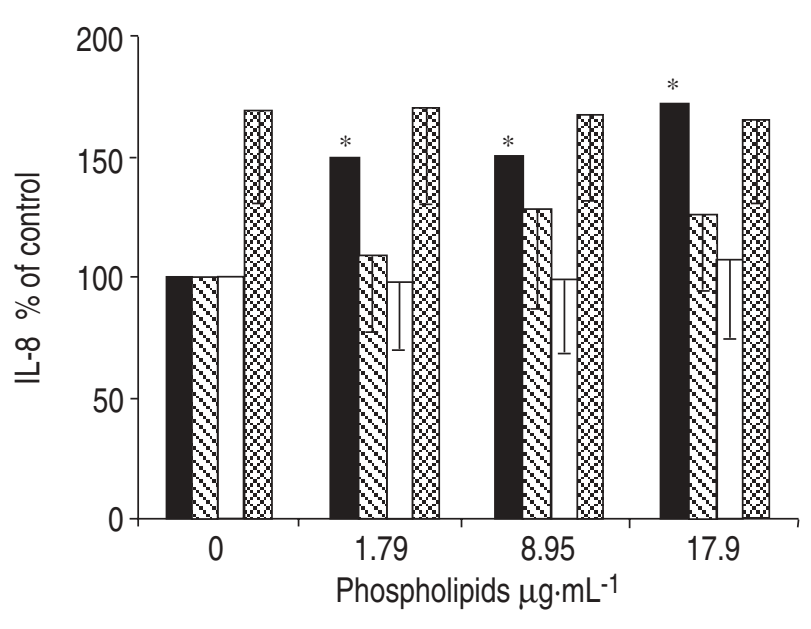

Fig. 5. - Interleukin (IL)-8 release from human peripheral monocytes cultured in the presence of different concentrations of unfractionated human surfactant $(\square)$, Curosurf $(\mathbb{\mathbb { Q }})$, Exosurf $(\square)$ and surfactant apoprotein A+Exosurf ( obtained from pulmonary alveolar proteinosis patients. Data are presented as mean \pm SD of three separate experiments. ${ }^{*}: \mathrm{p}<0.05$ with respect to control cells.

cells, the authors questioned whether a condition characterized by high concentrations of SP-A in the alveoli is associated with increased production of IL-8 and MCP-1. IL-8 and MCP-1 BALF levels were assessed in a group of PAP patients $(n=7)$ and a group of controls $(n=5)$. The number of BAL macrophages $\cdot \mathrm{mL}^{-1}$, and the number and percentages of BAL, lymphocytes and neutrophils were significantly higher among PAP patients than among unaffected subjects (table 2). Moreover, median IL-8 and MCP-1 levels in PAP patients were significantly higher than in controls. In addition, a significant correlation (Spearman rank correlation coefficient, $\mathrm{p}<0.05$ ) was found between IL-8 and MCP-1 and SP-A content in BAL.

\section{Discussion}

Macrophages and macrophage-derived chemokines are crucial for the initiation of inflammation in the lung by the recruitment and activation of specific cell subsets [31, 32]. Recent reports focused on immunoregulatory functions of SP-A, mostly directed towards monocytes and macrophages [5-17]. SP-A can stimulate macrophage antibacterial functions, in particular phagocytosis of several bacteria [8-11,14] including Mycobacterium tuberculosis [6]. Concerning phagocytosis of $M$. tuberculosis, maximal SP-A activity on human monocytes is exerted at $5 \mu \mathrm{g} \cdot \mathrm{mL}^{-1}$ (data not shown), i.e. at a concentration analogous to what was observed to be active on chemokine release.

SP-A activity on pro-inflammatory cytokine release is still controversial. SP-A has been shown to inhibit production of pro-inflammatory cytokines in response to LPS and to Candida albicans in peripheral mononuclear cells and alveolar macrophages respectively [33, 34]. In contrast, other studies showed that SP-A upregulates the production of TNF- $\alpha$, IFN- $\gamma$, IL-1 $\beta$, IL- 6 and IL- 8 by THP-1 cell line $[16,17]$ and that the addition of bovine surfactant lipids (Survanta) could inhibit SP-A activity on TNF- $\alpha$ but not on IL-8 release. The results of this study confirmed and extended these latter observations. First of all, it was found that SP-A significantly but differently stimulated the production of IL-8 and MCP-1 by two important lung cellular sources: monocytes and type-II cells. Moreover, SP-A activity on IL-8 was not counteracted by surfactant lipids, since surfactant was still able to stimulate IL-8 release by monocytes. In addition Curosurf and Exosurf did not significantly affect IL-8 release when assessed as single agents or when added to SP-A.

The molecular mechanisms of SP-A activity on monocytes have been studied by ScHAGAT et al. [35] who showed that SP-A stimulates a rapid tyrosine phosphorylation of specific macrophage proteins

Table 2. - Brochoalveolar lavage (BAL) features of controls and patients with pulmonary alveolar proteinosis (PAP)

\begin{tabular}{|c|c|c|c|c|c|c|c|c|c|c|}
\hline & Smoke & $\begin{array}{c}\text { Total } \\
\text { BAL cells } \\
1 \times 10^{6} \cdot \mathrm{mL}^{-1}\end{array}$ & $\begin{array}{l}\text { MA/Ly/ } \\
\mathrm{Ne} \%\end{array}$ & $\begin{array}{l}\text { Album } \\
\mathrm{mg} \cdot \mathrm{dL}^{-1}\end{array}$ & $\begin{array}{c}\text { SP-A } \\
\mu \mathrm{g} \cdot \mathrm{mL}^{-1}\end{array}$ & $\begin{array}{c}\mathrm{PL} \\
\mu \mathrm{g} \cdot \mathrm{mL}^{-1}\end{array}$ & $\begin{array}{c}\text { Total } \\
\text { proteins } \\
\mu \mathrm{g} \cdot \mathrm{mL}\end{array}$ & $\begin{array}{l}\text { SP-A:PL } \\
\text { ratio }\end{array}$ & $\begin{array}{c}\mathrm{IL8} \\
\mathrm{pg} \cdot \mathrm{mL}^{-1}\end{array}$ & $\begin{array}{l}\mathrm{MCP}-1 \\
\mathrm{pg} \cdot \mathrm{mL}^{-1}\end{array}$ \\
\hline \multicolumn{11}{|l|}{ Controls } \\
\hline 1 & No & 0.14 & $95 / 3 / 2$ & 1.88 & 1.2 & 2.8 & 212 & 0.429 & 14.02 & 9.51 \\
\hline 2 & No & 0.29 & $82 / 15 / 3$ & 7.2 & 0.70 & 63 & 230 & 0.011 & 17.1 & 4.98 \\
\hline 3 & No & 0.18 & $91 / 7 / 2$ & 3.1 & 1.1 & 38 & 60 & 0.029 & 0 & 21.17 \\
\hline 4 & Yes & 0.31 & $91 / 6 / 3$ & 2.6 & 1.8 & 34 & 102 & 0.053 & 9.5 & 7.3 \\
\hline 5 & Yes & 0.41 & $81 / 14 / 5$ & 14.2 & 0.8 & 52 & 190 & 0.015 & 0.45 & 36.89 \\
\hline Median & & 0.29 & $91 / 7 / 3$ & 3.1 & 1.1 & 38 & 190 & 0.03 & 9.5 & 9.5 \\
\hline \multicolumn{11}{|c|}{ PAP patients } \\
\hline 1 & No & 0.800 & $34 / 44 / 22$ & 12.1 & 53.1 & 37.8 & 343 & 1.40 & 12.54 & 309.18 \\
\hline 2 & No & 0.524 & $62 / 13 / 25$ & 173.0 & 99 & 370 & 4200 & 0.268 & 179.0 & 583.75 \\
\hline 3 & No & 0.759 & $72 / 25 / 2$ & 17.9 & 380 & 537 & 3070 & 0.708 & 123.0 & ND \\
\hline 4 & No & 0.323 & $65 / 19 / 16$ & 5.9 & 680 & 1200 & 6660 & 0.567 & 152.5 & 14.06 \\
\hline 5 & No & 0.687 & $53 / 29 / 18$ & 77.6 & 78.4 & ND & 383 & ND & 347.27 & 543.6 \\
\hline 6 & No & 0.320 & $46 / 26 / 28$ & 52.7 & 64 & 48.2 & 2405 & 1.32 & 68.73 & 3435.2 \\
\hline 7 & No & 0.130 & $68 / 24 / 8$ & 186 & 81 & 521.9 & 8500 & 0.15 & 151.95 & 954 \\
\hline Median & & 0.524 & $62 / 25 / 18^{*}$ & $52.7 *$ & $81^{*}$ & $445.95^{*}$ & $3070^{*}$ & $0.64 *$ & $151.95^{*}$ & $563.7^{*}$ \\
\hline
\end{tabular}

MA: macrophages; Ly: lymphocytes; Ne: neutrophils; SP-A: surfactant protein A; PL: phospholipids; IL8: interleukin-8; MCP-1: monocyte chemotactic peptide-1. *: $\mathrm{p} \leqslant 0.05$ between PAP ( $=7)$ and control patients $(\mathrm{n}=5)$. 
(similar to what has been observed for $\mathrm{IgG}$ ) and that maximal activity, consisting of tyrosine phosphorylation, protein kinase $\mathrm{C}$ activation and actin polymerization, is reached at concentrations ranging from 1-5 $\mu \mathrm{g} \cdot \mathrm{mL}^{-1}$. Moreover, Koptides et al. [36] found that SP-A can induce nuclear factor (NF)- $\kappa \mathrm{B}$ activation in THP-1 cells. The activation of these intracellular pathways is also a crucial event for the production of chemokines, including IL-8, by stimulated monocytes $[37,38,39]$. It is possible to speculate that the different stimulatory activities exerted by SP-A on monocytes and macrophages share common molecular pathways.

SP-A can bind directly to lipid A and to carbohydrate components of LPS and recent studies have stressed the importance of monitoring SP-A preparations for LPS contamination [28, 40]. A great effort was made to exclude the possibility that the effect of SP-A and Surf could be due to LPS contamination. In particular, the effect of an ef-SP-A preparation on IL-8 was tested and stimulatory activity was still detected. These data are in accordance with a recent observation by Song et al. [41] who observed a different mechanism of action between SP-A and LPS with respect to the activation of THP-1 cells.

In an attempt to ascertain the mechanism by which SP-A stimulates monocytes, some experiments with heat treated SP-A, ALSP-A, and with CRF or co-incubating cells with SP-A $+\alpha-\mathrm{MMP}$ were performed. These data suggested that the denaturated protein is not effective but the monomeric form of SP-A (ALSP-A), obtained by the alkylation of disulphide bridges, retains some stimulatory effect on IL-8. This result is in agreement with a previous observation [12] which provided evidence that neither alkylation nor reduction of SP-A affected its ability to enhance chemotaxis of macrophages. Some authors have suggested that the collagen-like domain of SP-A could be responsible for macrophage stimulation [42-44] by interacting with a specific $210-\mathrm{kDa}$ receptor expressed on monocytes and lymphocytes. This hypothesis is still controversial, since SP-A has also been shown to interact with leukocytes via mannosedependent binding to cell surface carbohydrates [45-47]. The results of this study seem to confirm this observation, since SP-A digestion by collagenase does not impair its activity on IL-8. As a consequence, the collagen tail of SP-A may not be necessary for this action. Conversely, the observation made here that $\alpha$-MMP is able to only partially (but not significantly) reverse SP-A effect does not provide definitive proof that the CRF domain is involved in monocyte activation.

Finally, the authors also tested whether these in vitro data could be of any relevance in vivo. Therefore, IL-8 and MCP-1 levels in BALF of controls and PAP patients were assessed. The results of this study, although obtained from a limited number of patients, seem to support the in vitro observations, since among PAP patients levels of IL- 8 and MCP-1 in BALF were significantly higher than among controls. This observation has been recently confirmed in a study by IYONAGA et al. [48] who detected higher BALF MCP-1 levels in PAP patients than in controls. It can therefore be inferred that SP-A induced modulation of chemokine levels in the airways may contribute to the recruitment of certain subclasses of effector inflammatory cells. This is consistent with an increase in the count of macrophages, neutrophils and lymphocytes in the BAL of PAP patients with respect to controls, a finding that is shared with other authors [49].

To conclude, evidence was found that surfactant apoprotein A can differently upregulate chemokine release from human monocytes and rat type-II cells. In addition, the in vitro results of this study are consistent with the high levels of interleukin-8 and monocyte chemotactic peptide-1 and the higher counts of neutrophils and lymphocytes that were found in the brochcoalveolar lavage of pulmonary alveolar proteinosis patients, thus suggesting that surfactant apoprotein A could contribute to the recruitment of inflammatory cells within the air spaces in this condition. Acknowledgements. The authors would like
to thank M. Gorrini for technical assistance.

\section{References}

1. Creuwels LAJM, van Golde LMG, Haagsman HP. The pulmonary surfactant system: biochemical and clinical aspects. Lung 1997; 175: 1-39.

2. Kuroki Y, Voelker DR. Pulmonary surfactant proteins. J Biol Chem 1994; 269: 25943-25946.

3. Shimizu M, Vayuvegula B, Ellis M, Gluck L, Gupta S. Regulation of immune functions by human surfactant. Ann Allergy 1988; 61: 459-462.

4. Pison U, Max M, Neuendank A, Weibbach S, Pietschmann S. Host defence capacities of pulmonary surfactant: evidence for "non-surfactant" functions of the surfactant system. Eur J Clin Invest 1994; 24: 586599.

5. Williams MD, Wright JR, March KL, Martin WJ. Human surfactant protein A enhances attachment of Pneumocystis carinii to rat alveolar macrophages. Am J Respir Cell Mol Biol 1996; 14: 232-238.

6. Pasula R, Downing JK, Wright JR, Martin WJ. Surfactant protein A (SP-A) mediates attachment of Mycobacterium tuberculosis to murine alveolar macrophages. Am J Respir Crit Care Med 1994; 149: A614.

7. Van Iwaarden JF, van Strijp JAG, Ebskamp MJM, Welmers AC, Verhoef J, van Golde LMG. Surfactant protein $\mathrm{A}$ is opsonin in phagocytosis of herpes simplex virus type 1 by rat alveolar macrophages. Am J Physiol 1991; 26: L204-L209.

8. Geertsma MF, Nibbering PH, Haagsman HP, Daha MR, van Furth R. Binding of surfactant protein A to $\mathrm{Clq}$ receptors mediates phagocytosis of Staphylococcus aureus by monocytes. Am J Physiol 1994; 267: L578-L584.

9. Tenner AJ, Robinson SL, Borchelt J, Wright JR. Human pulmonary surfactant protein (SP-A), a protein structurally homologous to $\mathrm{C} 1 \mathrm{q}$, can enhance FcR- and CR1-mediated phagocytosis. J Biol Chem 1989; 264: 13923-13928.

10. Tino MJ, Wright JR. Surfactant protein A stimulates 
phagocytosis of specific pulmonary pathogens by alveolar macrophages. Am J Physiol 1996; 270: L677-L688.

11. Kabha KJ, Schmegner Y, Keisari Y, Parolis H, Schlepper-Schaefer J, Ofek I. SP-A enhances phagocytosis of Klebsiella by interaction with capsular polysaccharides and alveolar macrophages. Am J Physiol 1997; 272: L344-L352.

12. Wright JR, Youmans DC. Pulmonary surfactant protein A stimulates chemotaxis of alveolar macrophage. Am J Physiol 1993; 264: L338-L344.

13. Weissbach S, Neuendank A, Pettersson M, Schaberg $T$, Pison U. Surfactant protein A modulates release of reactive oxygen species from alveolar macrophages. Am J Physiol 1994; 267: L660-L666.

14. Mariencheck WI, Savov J, Dong Q, Tino MJ, Wright JR. Surfactant protein A enhances alveolar macrophage phagocytosis of a live, mucoid strain of $P$. aeruginosa. Am J Physiol 1999; 277: L777-L786.

15. Blau H, Riklis S, Kravtsov V, Kalina M. Secretion of cytokines by rat alveolar epithelial cells: possible regulatory role for SP-A. Am J Physiol 1994; 266: L148-L155.

16. Kremlev SG, Phelps DS. Surfactant protein A stimulation of inflammatory cytokine and immunoglobulin production. Am J Physiol 1994; 267: L712L719.

17. Kremlev SG, Umstead TM, Phelps DS. Surfactant protein A regulates cytokine production in the monocytic cell line THP-1. Am J Physiol 1997; 272: L996L1004.

18. Car BD, Meloni F, Luisetti M, Semenzato G, Gialdroni Grassi G, Walz A. Elevated IL-8 and MCP-1 in the bronchoalveolar lavage fluid of patients with idiopathic pulmonary fibrosis and pulmonary sarcoidosis. Am J Respir Crit Care Med 1994; 149: 655-659.

19. Kunkel SL, Standiford T, Kasahara K, Strieter RM. Interleukin-8 (IL8): the major neutrophil chemotactic factor in the lung. Exp Lung Res 1991; 17: 17-23.

20. Kunkel SL, Lukas N, Strieter RM. Chemokines and their role in human disease. Agents-Actions Suppl 1995; 46: 11-22.

21. Alberti A, Luisetti M, Braschi A, et al. Bronchoalveolar lavage fluid composition in alveolar proteinosis. Early changes after therapeutic lavage. $A m$ J Respir Crit Care Med 1996; 154: 817-820.

22. Klech H, Pohl W. Technical recommendations and guidelines for bronchoalveolar lavage (BAL). Eur Respir J 1989; 2: 516-585.

23. Alberti A, Ravenna F, Quaglino D, et al. In chyloptysis, SP-A affects the clearance of serum lipoproteins entering the airways. Am J Physiol 1998; 274: L737-L749.

24. Hagwood S, Benson BJ, Shilling J, Damm D, Clements JA, White RT. Nucleotide and amino acid sequence of pulmonary surfactant protein SP18 and evidence for co-operation between SP 18 and SP 28-36 in surfactant lipid adsorption. Proc Natl Acad Sci USA 1987; 84: 66-70.

25. Goldstein JL, Basu SK, Brown MS. Receptor mediated endocytosis of low density lipoproteins in cultured cells. Methods Enzymol 1983; 98: 241-260.

26. Haagsman HP, Sargeant T, Hauschka PV, Benson BJ, Hangood S. Binding of calcium to SP-A, a surfactant associated protein. Biochemistry 1990; 29: 8894 8900.
27. Baritussio A, Alberti A, Quaglino D, et al. SP-A, SP-B, and SP-C in surfactant subtypes around birth: reexamination of alveolar life cycle of surfactant. $\mathrm{Am}$ J Physiol 1994; 266: L436-L447.

28. Wright JR, Zlogar DF, Taylor JC, Zlogar TM, Restrepo CI. Effect of endotoxin on surfactant protein $\mathrm{A}$ and $\mathrm{D}$ stimulation of $\mathrm{NO}$ production by alveolar macrophages. Am J Physiol 1999; 276: L650L658.

29. Dobbs LG, Gonzalez R, Williams MC. An improved method for isolating type-II cells in high yield and purity. Am Rev Respir Dis 1986; 134: 141-145.

30. Metcalf JA, Gallin JI, Nauseef WM, Root RK eds. Laboratory manual of neutrophil function. New York, Raven Press, 1986.

31. Strieter RM, Kunkel SL. Chemokines in the lung. In: Crystal R, West J, Weibel E, Barnes P, eds. Lung: Scientific Foundation. 2nd edition. New York, Raven Press, 1997; pp. 156-186.

32. Luster AD. Chemokines-chemotactic cytokines that mediate inflammation. $N$ Engl J Med 1998; 338: 436445.

33. Borron P, McIntosh JC, Korfhagen TR, Whitsett JA, Taylor J, Wright JR. Surfactant-associated protein A inhibits LPS-induced cytokine and nitric oxide production in vivo. Am J Physiol Lung Cell Mol Physiol 2000; 278: L840-L847.

34. Rosseau S, Hammerl P, Maus U, et al. Surfactant protein A down-regulates proinflammatory cytokine production evoked by Candida albicans in human alveolar macrophages and monocytes. J Immunol 1999; 163: 4495-4502.

35. Schagat TL, Tino MJ, Wright JR. Regulation of protein phosphorylation and pathogen phagocytosis by surfactant protein A. Infect Immun 1999; 67: 46934699.

36. Koptides M, Umstead TM, Floros J, Phelps DS. Surfactant protein A activates NF- $\mathrm{BB}$ in the THP-1 monocytic cell line. Am J Physiol 1997; 273: L382L388.

37. Lee JC, Laydon JT, McDonnel PC, et al. A protein kinase involved in the regulation of inflammatory cytokine biosynthesis. Nature 1994; 372: 739-746.

38. Sanghera JS, Weinstein SL, Aluwalia M, Girn J, Pelech SL. Activation of multiple proline directed kinases by bacterial lipopolysaccharide in murine macrophages. J Immunol 1996; 156: 4457-4465.

39. Cristelle M, Roman-Roman S, Rawadi G. Involvement of mitogen-activated protein kinase pathways in interleukin- 8 production by human alveolar monocytes and polymorphonuclear cells stimulated with lipopolysaccharide or Mycoplasma fermentans membrane lipoproteins. Infect Immun 1999; 67: 688-693.

40. Stamme C, Wright JR. Surfactant protein A enhances the binding and deacylation of E. coli LPS by alveolar macrophages. Am J Physiol 1999; 276: L540-L547.

41. Song M, Phelps DS. Comparison of SP-A and LPS effect on the THP-1 monocytic cell line. Am J Physiol Lung Cell Mol Physiol 2000; 279: L110-L117.

42. Borron P, McCormack FX, Elhalwagi BM, et al. Surfactant protein A inhibits T cell proliferation via its collagen-like tail and a 210-kDa receptor. Am J Physiol 1998; 275: L679-L686.

43. Malhotra R, Haurum J, Thiel S, Sim RB. Interaction of $\mathrm{Clq}$ receptor with lung surfactant protein A. Eur J Immunol 1992; 22: 1437-1445.

44. Oosting RS, Wright JR. Characterization of the 
surfactant protein A receptor: cell and ligand specificity. Am J Physiol 1994; 267: L165-L171.

45. Wintergerst E, Manz-Keinke H, Plattner H, SchlepperSchafer $\mathrm{J}$. The interaction of a lung surfactant protein (SP-A) with macrophages is mannose-dependent. Eur J Cell Biol 1989; 50: 291-298.

46. Chrouch EC. Collectins and pulmonary host defense. Am J Respir Cell Mol Biol 1998; 19: 177-201.

47. Manz-Keinke H, Egenhofer C, Plattner H, SchlepperSchafer J. Specific interaction of lung surfactant protein A (SP-A) with rat alveolar macrophages. Exp Cell Res 1991; 192: 597-603.

48. Iyonaga $\mathrm{K}$, Suga $\mathrm{M}$, Yamamoto $\mathrm{T}$, Ichiyasu $\mathrm{H}$, Miyakawa H, Ando M. Elevated bronchoalveolar concentration of MCP-1 in patients with pulmonary alveolar proteinosis. Eur Respir J 1999; 14: 383-389.

49. Milleron BJ, Costabel U, Teschler H, et al. Bronchoalveolar lavage cell data in alveolar proteinosis. $\mathrm{Am}$ Rev Respir Dis 1991; 144: 1330-1332. 